\title{
Assessment, investigation, and early management of head injury: summary of NICE guidance
}

Clarification-This NICE guideline summary (BMJ 2007;335:719, doi:10.1136/bmj.39331.702951.47) has now been superseded by a summary of updated guidance at www. bmj.com/content/348/bmj.g104.
Cite this as: BMJ 2013;346:9409

๑ BMJ Publishing Group Ltd 2014 